\title{
SECTION 8(a) (3) OF THE NLRA AND THE EFFORT TO INSULATE FREE EMPLOYEE CHOICE
}

\author{
Julius G. GetMan*
}

CEction 8(a)(3) of the National Labor Relations Act makes it an 1 unfair labor practice for an employer "by discrimination in regard to hire or tenure of employment or any term or condition of employment to encourage or discourage membership in any labor organization." 1 The purpose of this section is "to allow employees to freely exercise their right to join unions, be good, bad, or indifferent members, or abstain from joining any union without imperiling their livelihood."2 In accord with this policy the Court has held that to "encourage or discourage membership" means also to encourage or discourage participation in union activities or fulfillment of union obligations. ${ }^{3}$

Since almost any employer response to union activity will have a tendency to encourage or discourage union membership, the development of rules governing application of section 8(a)(3) has necessarily involved an attempt to achieve a compromise between the employee's interest in freely choosing whether or not to engage in union activity and the employer's interest in running his business as he sees fit. ${ }^{4}$ Hence, the most sensible method of determining whether section 8(a)(3) applies in a given type of case is by balancing the importance of the employer's interest against the likely degree of encouragement or discouragement of union membership. This approach is widely employed, and there is considerable language in the opinions stressing its importance. ${ }^{5}$

But like many forms of rational behavior, balancing interests against one another is easier to subscribe to in theory than it is to put into practice. It is time consuming and conflicts with the desire that the law be certain. As a result it is not surprising that balancing of interests is

* Associate Professor of Law, Indiana University.

149 Stat. 452 (1935), as amended, 29 U.S.C. § 158(2)(3) (1958).

2 Radio Officers' Union v. NLRB, 347 U.S. 17, 40 (1954).

3 Id. at $39-42$.

4 See, e.g., NLRB v. Babcock \& Wilcox Co., 351 U.S. 105 (1956); NLRB v. Mackay Radio \& Tel. Co., 304 U.S. 333 (1938).

5 See, e.g., NLRB v. Erie Resistor Corp., 373 U.S. 221, 228-29 (1963); NLRB v. Truck Drivers Union, 353 U.S. 87 (1957). 
often discarded by both the Board and the courts in favor of more objective standards, which would be acceptable if they adequately recognized the interests likely to be affected. ${ }^{6}$ But the Board frequently applies section $8(a)(3)$ mechanically without considering legitimate employer interests. The courts, on the other hand, have responded by developing standards which require a finding that section 8(a)(3) was not violated even where careful weighing of interests would suggest its application. The purpose of this article is to explore the interplay between the Board and the courts and to evaluate the standards which have been developed to govern application of section 8(a)(3).

\section{The Definition of Discrimination}

One possible way to limit application of section $8(a)(3)$ is to construe the word discrimination narrowly. Several recent judicial opinions have suggested that an employer does not discriminate unless he treats union

6 Thus both the Board and the courts automatically find a violation when an employer treats union members differently from non-union members. A per se approach is justifiable in this context. The encouragement or discouragement is dixect; any employee deciding whether to join a union will take the employer's actions into account. In NLRB v. Gaynor News Co., 197 F.2d 719 (2d Cir. 1952), the employer granted special benefits to union members which were denied to non-union members. He argued that he had not violated section $8(a)(3)$ because his "action had neither the purpose nor the effect ... to encourage membership in any labor organization." The Court of Appeals for the Second Circuit rejected this argument because "discriminatory conduct, such as that practiced here, is inherently conducive to increased union membership." Id. at 722. The Supreme Court affirmed on certiorari. Radio Officers' Union v. NLRB, 347 U.S. 17 (1954). It specifically approved the per se approach based on disparate treatment of union members and non-union members. "In holding that a natural consequence of discrimination, based solely on union membership or lack thereof, is discouragement or encouragement of membership in such union, the court merely recognized a fact of common experience-that the desire of employees to unionize is directly proportional to the advantages thought to be obtained from such action." Id. at 46. Moreover, it is difficult to conceive of a strong employer interest in drawing such a distinction.

An employee might seek to justify drawing a distinction between union members and non-union members in several ways. He could argue that having union men and non-union men working together caused or is likely to cause turmoil in the shop. This justification was rejected in NLRB v. Star Publishing Co., 97 F.2d 465 (9th Cir. 1938). An employer has sufficient power under the act to deal individually with those who violate rules of discipline. Experience indicates that serious turmoil can be avoided by a determined employer. Moreover, a certain amount of agitation must necessarily be tolerated as the price of the free discussion which is essential for free choice.

An employer could argue that he was forced by union or employee pressure to draw such a distinction. The answer here is that he must resist the pressure by either disciplining the employees or filing a charge against the union. See NLRB v. Gluek Brewing Co., 144 F.2d 847 (8th Cir. 1944). An employer might argue that union men are likely to behave in certain improper ways and that he is justified in taking action in advance to avoid this. But of course this argument runs counter to the basic purpose of section $8(a)(3)$, which seeks to prevent an employer from using his views of unions and their members as the basis for punishing or rewarding employees. 
members or employees who engaged in union activity differently from the way he treats other employees. ${ }^{7}$ Although such a definition of discrimination is consistent with the common understanding of the term it is inconsistent with the policy of insulating union activity from reprisals on the job. It would make section 8(a)(3) inapplicable to cases when retaliation against the union activity of some employees affects all employees. And it would probably require a court to hold that there was no violation of section 8(a)(3) when a company applied a rule to union activity which would also be applied in other situations.

A narrow definition of discrimination was urged on the Court and rejected in Republic Aviation Corp. $v . N L R B .{ }^{8}$ The employer discharged an employee for soliciting union membership in violation of a long standing company rule prohibiting "soliciting of any type."9 The Board found that the rule as applied to union solicitation constituted a violation of section $8(a)(1)$ because it interfered with the right of self-organization and that the discharge pursuant to the rule violated section 8(a)(3). The Supreme Court agreed. Since the rule was applied to all cases, not only those involving union solicitation, the company argued that there was no discrimination. The Court dealt with this argument in the following cryptic passage:

Petitioner urges that $[i t] \ldots$ did not violate section $8(3) \ldots$ because the rule was not discriminatorily applied against union solicitation but was impartially enforced against all solicitors. It seems clear, however, that if a rule against solicitation is invalid as to union solicitation on the employer's premises during the employee's own time a discharge because of violation of that rule discriminates within the meaning of [section] $8(3)$, in that it discourages membership in a labor organization.10

The Court's analysis is unclear: to the extent the opinion equates discrimination with discouragement it denies any separate meaning to the former. But it is clear that the Court used discrimination to signify something other than a distinction between employees. The only way in which it may properly be said that the employer discriminated was in treating these employees differently from the way he would have treated them had they not engaged in union solicitation. Discrimination as thus used includes any employer action taken in response to union activity.

7 Local 357, Teamsters Union v. NLRB, 365 U.S. 667, 675 (1961); NLRB v. Miranda Fuel Co., 326 F.2d 172, 176 (2d Cir. 1963); NLRB v. Great Fall Employers' Council, Inc., 277 F.2d 772, 775 (9th Cir. 1960).

8324 U.S. 793 (1945).

9 Id. at 795.

$10 \mathrm{Id}$. at 805 . 
The point is illustrated by Allis-Chalmers Mfg. Co. $v$. NLRB, where the employer reclassified everyone, members and nonmembers alike, in a unit which voted in favor of a union. The Seventh Circuit held that the employer violated sections $8(a)(1)$ and (3) "so long as that action would not have been taken in the absence of such union activity." 12 Here too the court correctly construed discrimination to include employer response to union activity. The policy of insulating employees' jobs from their union activity or membership usually applies with as much force to cases of general retaliation as to cases in which the employer singles out those who engaged in union activity for special treatment. And the employer's interest does not appear to be any greater.

\section{The Treatment of Discrimination Based on Union Activity}

In cases where discrimination is based on employer response to union activity the Board has generally determined the applicability of section 8 (a)(3) by balancing the importance of the union activity and the extent of its infringement by the employer ${ }^{13}$ against the importance of the employer's interest. The fact that an employer's conduct serves a legitimate business purpose is relevant in two ways. It sets an important interest in opposition to the interest of free employee choice and makes it less likely that the action will be construed as a threat to all union activity. On the other hand it is well settled that if an employer is motivated by anti-union animus his action violates section $8(a)(3)$ even though it serves a valid business purpose and would otherwise have been permissible. ${ }^{14}$

11162 F.2d 435 (7th Cir. 1947).

12 Id. at 440. See also Armstrong Cork Co. v. NLRB, 211 F.2d 843 (5th Cir. 1954); NLRB v. Somerset Shoe Co., 111 F.2d 681 (1st Cir. 1940).

13 Relevant factors may include the number of employees involved, the extent to . which the employer's rule is likely to affect a particular kind of union activity, the nature of the discipline, and the likelihood that the employer's conduct will be seen as a limited response to particular concerted activity rather than to a general feeling about unions. To some extent the degree of discouragement which occurs in such cases turns on whether the employees consider the act of the employer a reflection of his basic hostility to unions in general.

14 Where the employer is in fact motivated by hostility to unions, a violation is automatically found. See, e.g., NLRB v. Erie Resistor Corp., 373 U.S. 221, 227-28 (1963); NLRB v. Babcock \& Wilcox Co., 351 U.S. 105, 111 n.4 (1956); NLRB v. Stowe Spinning Co., 336 U.S. 226, 230-33 (1949). If the employer's conduct serves a legitimate business purpose, the fact is relevant in two ways. First, it sets an important interest in opposition to the interest of free employee choice, and second, it makes it less likely that the action will be construed as a threat to all union activity.

The distinction between valid business considerations and anti-union animus is not always apparent. In NLRB v. Lassing, 284 F.2d 781 (6th Cir. 1960), an employer 
By and large when the Board has carefully weighed competing interests, the courts have accepted its decisions. ${ }^{15}$ As noted above, where the Board has failed to consider important interests, the courts have responded by denying enforcement of the Board's orders without undertaking to

assumed that the presence of the union would lead to increased costs. Partly on the basis of this conclusion he eliminated three jobs. The Board found a violation of \$ 8(a)(3). The court of appeals denied enforcement on the grounds that: "The advent of the Union was a new economic factor which necessarily had to be evaluated by the respondent as a part of the overall picture pertaining to costs of operations. . . There is no evidence [of] . . . anti-union background. . . . The change was made because of reasonably anticipated increase costs, regardless of whether this increased cost was caused by the advent of the Union or by some other factor entering into the picture." Id. at 788 .

If this approach were generally followed, the result would be unfortunate. Almost any conduct which penalizes employees for union membership or activity can be described in other terms. An employer who discharges employees for joining the union could claim that his actions were meant to prevent the turmoil which often occurs when some employees are union men and others are not. Typically, however, such excuses are not permitted. See cases cited in note 6 supra. In many cases anti-union animus is based not on political convictions but on an evaluation of what effect unionization will have on profits, industrial relations, or plant conditions. Neither the Board nor the courts are equipped to separate the factors which influenced an employer in order to determine whether he was unhappy with union organization because of relevant economic considerations or because of an intent to evade the act. It seems highly unlikely that state of mind is often cast in terms of a pure and simple desire to violate the act. Nor would it be desirable to permit an employer to take into account union affiliation to the extent that a court thinks this factor reasonably related to economic reality. Such a rule would permit the economic views of individual judges to have significant impact on our labor laws.

15 In Erie Resistor Corp., 132 N.L.R.B. 621 (1961), the Board held that granting superseniority to strike replacements violated $\S 8(\mathrm{a})(3)$. It is well settled that in an economic strike an employer may, in order to continue operation, hire permanent replacements even if striking employees will have to be laid off. NLRB v. McKay Radio \& Tel. Co., 304 U.S. 333 (1938). The employer in Erie Resistor argued that since superseniority was granted to assure that replacements were available it served the same legitimate employer interest and therefore should be permitted. The Board recognized that a legitimate purpose was served, but it carefully pointed out the ways in which permitting an employer to hire replacements and to grant them superseniority is more likely to discourage participation in strike activity than merely permitting replacement. Erie Resistor Corp., supra at 625-30. The Supreme Court affirmed and adopted the Board's reasoning. NLRB v. Erie Resistor Corp., 273 U.S. 221, 230-32 (1963). See also NLRB v. Truck Drivers Union, 353 U.S. 87 (1957) (upholding the Board's decision in Buffalo Linen Supply Co., 109 N.L.R.B. 447 (1954) that the employer's interest in multi-employer bargaining was worthy of special recognition); Radio Officers' Union v. NLRB, 347 U.S. 17 (1954), enforcing, 93 N.L.R.B. 299 (1951), 93 N.L.R.B. 1523 (1951), and 94 N.L.R.B. 1494 (1951); Republic Aviation Corp. v. NLRB, 324 U.S. 793 (1945), enforcing, 54 N.L.R.B. 1253; Local 79, Teamsters Union v. NLRB, 325 F.2d 1011 (D.C. Cir. 1963), upholding the Board's decision in Redwing Carriers, Inc., 137 N.L.R.B. 1545 (1962), that the employer's interest in efficient operation permits an employer to discharge employees who refuse to cross a picket line. It is interesting to note that in all of these decisions the courts stressed the discretion given the Board under the Act. 
correct the Board's failure to balance. The extent to which the Board's approach shapes the courts' response is demonstrated by the cases dealing with an employer's ability to apply existing company rules to employees who engaged in union activity. Where no-solicitation or no-distribution rules are applied to union activity, the Board carefully weighs the interest of the union in having its message heard against the amount of potential interference with efficient operations. ${ }^{16}$ Generally the courts affirm the Board; even if they do not, they undertake to reevaluate the competing interests. ${ }^{17}$ But in cases involving other types of rules which are logically indistinguishable from the solicitation cases the Board

16 The balancing is directed to the question of whether the company's rule violated $\S 8(\mathrm{a})(\mathrm{I})$. If the rule violates $\S 8(\mathrm{a})(\mathrm{I})$ union solicitation contrary to it is protected by $\S 7$. In such cases discipline of the employee violates $\S 8(a)(3)$. Stoddard-Quirk Manufacturing Co., 138 N.L.R.B. 615 (1962); May Department Store Co., 136 N.L.R.B. 797 (1962); Peyton Packing Co., 49 N.L.R.B. 828, 843-44 (1943).

Application of $\S 8(a)(3)$ may involve a similar balancing of interests directed to the question of whether union activity is protected by Section 7 . Thus where an employee presses a contractual grievance under the established machinery, he is engaged in protected activity even if the union considers the claim non-meritorious. If he is discharged for processing his claim the discharge violates $\$ \S 8(a)(3)$ and (1). Farmers Union Co-op. Marketing Ass'n, 145 N.L.R.B. 1 (1963). But where an individual presses his own claim outside the grievance machinery he is not engaged in protected activity and $\S 8(\mathrm{a})(3)$ is not violated if he is discharged. $\mathrm{R}$. J. Tower Iron Works, Inc., 144 N.L.R.B. 445 (1963). The Board draws the distinction because it views the general employee interest in having the grievance machinery utilized as more important than the interest in having an individual grievance settled informally. See Farmers Union Co-op. Marketing Ass'n, supra at 3. Similarly, intermittent work stoppages to protest an employer's unfair labor practices are protected and a subsequent discharge violates $\S 8(a)(3)$. Blades Mfg. Corp., 144 N.L.R.B. 561 (1963). But intermittent work stoppages for the purpose of utilizing bargaining pressure are unprotected. UAW v. Wisconsin Employment Relations Bd., 336 U.S. 245 (1949). The employer's interest in continuity of operations which makes the conduct unprotected in a bargaining context is not deemed worthy of protection when the employer is guilty of violating the act. Blades Mfg. Corp., supra. The same type of balancing is utilized to determine whether picket line activity loses the protection of the act because of minor misconduct. Thus in Bonnar Vawter, Inc., 129 N.L.R.B. 127 (1960), enforced, $289 \mathrm{~F} .2 \mathrm{~d} 133$ (1st Cir. 1961), the Board found that three striking employees who pretended that they were putting nails in a driveway were engaged in protected activity. Their discharge was held to be a violation of $\$ 8(a)(3)$. In Brookville Glove Co., 114 N.L.R.B. 213 (1955), enforced, 234 F.2d 400 (3d. Cir. 1956), threats of violence were held sufficient to deprive employees of their right to reinstatement.

17 NLRB v. United Steelworkers, 357 U.S. 357 (1958); NLRB v. Babcock \& Wilcox Co., 351 U.S. 105 (1956); Republic Aviation Corp. v. N.L.R.B. 324 U.S. 793 (1945); NLRB v. United Aircraft Corp. 324 F.2d 128 (2nd Cir. 1963).

In some cases the question is whether an important business interest permits an employer to penalize employees who engaged in protected union activity. Thus, an employer may replace economic strikers even permanently in order to keep his business operating, NLRB v. Mackay Radio \& Tel. Co., 304 U.S. 33 (1938), but he may not discharge the employees or replace them in order to punish them. NLRB v. Buzza-Cardoza, 205 F.2d 889 (9th Cir. 1953). Refusal to cross a picket line is protected concerted activity, but the employee may be discharged where it is "clear ... that the employer acted only to preserve ... operation of his business." Redwing Carriers, Inc., 137 N.L.R.B. 1545, 1547 (1962), petition to set aside denied, 325 F.2d 1011 (D.C. Cir. 1963), cert. denied, 377 U.S. 905 (1964). 
applies section $8(a)(3)$ mechanically,, 18 and the courts refuse to find a violation unless it can be shown that the employer acted for the purpose of discouraging union membership. ${ }^{19}$

Typical is Quality Castings Co. v. $N L R B .{ }^{20}$ In that case an employer acted in accordance with a profit sharing plan which provided for forfeiture on the basis of a percentage of unexcused absences during a particular period. As a result, certain employees who were on strike during the period did not receive their bonuses. The Board held that this approach violated the act since it rested on "the faulty premise that time on strike may lawfully be considered the equivalent of normal absence for purposes of determining profit-share forfeiture."21 The court of appeals reversed:

We are of the opinion that when, as in this case, an employer's action is not specifically directed against those who have engaged in protected types of union activity but is rather directed at a group which is defined by other than union membership or activity criteria, and which clearly includes others who did not engage in the protected, concerted activities, the Board not only must prove discrimination but also it must prove the employer's motivation. ${ }^{22}$

Although the emphasis on motive is unfortunate, the result reached by the court of appeals seems sound. Where the employer applies uniform criteria which predate the particular situation, it makes sense to

18 National Seal Co., 141 N.L.R.B. 661 (1963); Quality Castings Co., 139 N.L.R.B. 928 (1962); Pittsburgh-Des Moines Steel Co., 124 N.L.R.B. 855 (1959).

19 NLRB v. National Seal Co., 336 F.2d 781 (9th Cir. 1964); Quality Castings Co. v. NLRB, 325 F.2d 36 (6th Cir. 1963); Pittsburgh-Des Moines Steel Co. v. NLRB, 284 F.2d 74 (9th Cir. 1960).

20336 F.2d 781 (9th Cir. 1964).

21139 N.L.R.B. 928,930 (1962).

22325 F.2d at 41. See also Pittsburgh-Des Moines Steel Co. v. NLRB, 284 F.2d 74 (9th Cir. 1960). In that case the company had a general policy of giving Christmas bonuses when it could afford to. In 1957 the company by resolution excluded from the bonus "the striking employees at the Santa Clara Plant." The company argued that its decision was based upon application of a formula, components of which were productivity and continuity of work effort at the individual plants. The striking employees were excluded, the company argued, not because they had gone on strike but because they did not perform well on these items in the program. The Board found a violation. It concluded that even if the employer was not improperly motivated, "the conclusion is inescapable that in applying its five factor formula . . . respondent discriminated against such employees solely on the basis of their participation in a prolonged strike. It is of course obvious that such discriminatory treatment tends to discourage future strike action by respondent's employees." Pittsburgh-Des Moines Steel Co., 124 N.L.R.B. 855, 858 (1959). The court of appeals reversed: "When criteria other than union membership or activity are used as the basis for an employer's discrimination .... it is then up to the Board to predicate a conclusion of unlawful intent upon ... . specific evidence; a showing of the discriminatory treatment plus its natural and foreseeable consequences will not suffice." $284 \mathrm{~F} .2 \mathrm{~d}$ at 83. 
grant him considerable leeway. For in such cases it is likely that whatever discouragement of union activities occurs will be limited to the particular activity involved and will not include union membership or activity in general. There is little reason to believe that the employees will expect general retaliation against union membership. Moreover, the fact that the employer applies these standards in situations which do not involve union activity indicates that there is a legitimate business interest involved.

An employer should be permitted to withhold the payment of benefits on the basis of criteria which reflect participation in concerted activity, particularly where the benefits are in some way attributable to work which the employee did not perform. An employer may, after all, withhold wages during a strike, and employees know that strike action involves forfeiture of immediate benefits and the risk of permanent replacement. The amount of additional discouragement which would occur were there also the possibility of loss of a bonus or other future benefits seems minimal, especially since it is possible for this to be taken into account in the strike settlement.

On the other hand, where the imposition of a penalty is involved the case for finding a violation is often stronger, particularly if the penalty will have permanent effect. In such cases the approach taken by the courts of appeals leads to more questionable results. Thus, in NLRB $v$. National Seal, ${ }^{23}$ an employer dismissed probationary employees who had participated in a strike on the basis of a long-standing rule that probationary service had to be continuous and unbroken. Without carefully weighing the competing interests, the Board found a violation of section 8(a)(3).24 The Court of Appeals for the Ninth Circuit denied enforcement. The result of the court's decision was to deprive all probationary employees of the right to strike, the special importance of which has been recognized both by Congress and the courts. ${ }^{25}$ The employer's interest was minor, particularly since he could have extended the probationary period to provide the necessary period of continuous service. The application of such a rule to strike activity seems no less destructive of statutory rights than application of the no-solicitation rule in the Republic Aviation case. ${ }^{26}$ Unfortunately neither the Board nor the Ninth Circuit went beyond generalities in judging the legality of the employer's conduct.

23336 F.2d 781 (9th Cir. 1964).

24 National Seal Co., 14I N.L.R.B. 661 (1963).

-25 See $\S 13$ of the act; NLRB v. Erie Resistor Corp., 373 U.S. 221, 233 (1963).

26324 U.S. 793 (1945). 


\section{The Importance of Employer Motive}

The most frequently used technique for limiting application of section $8(a)(3)$ has been to require a showing that the employer was motivated by a desire to discourage union membership. Since the courts have not insisted upon such a showing when the Board has carefully weighed competing interests, there exist two lines of cases dealing with section 8(a)(3). In one a finding of violation turns on a finding of improper motive; ${ }^{27}$ in the other it turns on balancing of interests. ${ }^{28}$ This dichotomy reflects long-standing confusion concerning the relevance of the employer's state of mind to a finding of violation of section 8(a)(3). In part the confusion stems from the failure of the courts to recognize that employers use motive as a defense in two very different ways. The typical 8(a)(3) case involves the discharge or discipline of an employee active in union activities. The employer defends on the grounds that the discharge was not based on union activity, but on poor work or misconduct. In the second type of case the employer seeks to defend action admittedly taken in response to union activity on the grounds that it was intended to serve a proper business purpose.

In the former class of cases a legitimate motive constitutes a valid defense. Proof of proper motive is also proof that union activity was not the basis for the employer's actions. It has always been recognized that union membership does not insulate an employee from discipline. ${ }^{20}$ Although such a discharge may discourage union membership, there is no discrimination for purposes of section 8(a)(3) since the differentiation between employees is not related to union activity or membership. The impact on the union is fortuitous. Such cases were the first dealt with by the courts, and from the beginning opinions in these cases have stressed the importance of motive. ${ }^{30}$ In context this is unobjection-

27 American Ship Bldg. Co. v. NLRB, 380 U.S. 300 (1965); Local 357, Teamsters Union v. NLRB, 365 U.S. 667 (1961); Quality Castings Co. v. NLRB, 325 F.2d 36 (6th Cir. 1963); NLRB v. Daiton Brick \& Tile Corp., 301 F.2d 886, 896 (5th Cir. 1962); Pittsburgh-Des Moines Steel Co. v. NLRB, 284 F.2d 74 (9th Cir. 1960); NLRB v. Great Falls Employers' Council, Inc., 277 F.2d 772 (9th Cir. 1960). Even opinions which stress the necessity for a finding of improper motive recognize an exception for cases in which the discrimination is based on union membership. See Pittsburgh-Des Moines Steel Co. v. NLRB, supra; American Ship Building Co. v. NLRB, supra.

28 See, e.g., NLRB v. Erie Resistor Corp., 373 U.S. 221 (1963); Radio Officers' Union v. NLRB, 347 U.S. 17 (1954); Republic Aviation Corp. v. NLRB, 324 U.S. 793 (1945); Summit Mining Corp. v. NLRB, 260 F.2d 894 (3d Cir. 1958); Cusano v. NLRB, 190 F.2d 898 (3d Cir. 1951); Allis-Chalmers Mfg. Co. v. NLRB, I62 F.2d 435 (7th Cir. 1947).

20 See, e.g., NLRB v. Jones \& Laughlin Steel Corp., 301 U.S. 1, 45-46 (1937).

30 Ibid: "The Act does not interfere with the normal exercise of the right of the employer to select its employees or to discharge them .... The Board is not entitled to make its authority a pretext for interference with the right of discharge when that 
able. But the courts have often simply assumed the applicability of this language to cases in which the employer admittedly acts on the basis of union activity. And although the Supreme Court has upheld a finding of violation without a finding of improper motive on at least three occasions, ${ }^{31}$ its language has been so highly equivocal that no clear picture of the significance of motive has emerged.

Republic Aviation Corp. v. NLRB ${ }^{32}$ was the first case in which application of section $8(a)(3)$ was upheld by the Court although the employer was not motivated by hostility to the union. The significance of the decision has been obscured by the fact that the company acted pursuant to a rule which has been found to violate section $8(a)(1)^{33}$ and because, as noted above, the Court's discussion of section $8(a)(3)$ was short and confusing.

The first full discussion by the Court of the requirement of motive under section $8(a)(3)$ was in Radio Officer's Union $v . N L R B,{ }^{34}$ where the Court held that discharge or refusal to hire an employee for failure to meet his union obligations constituted a violation of section 8(a)(3). The Court rejected the defense that the employer "did not intend to discourage." It found that "since ... the employers intended to discriminate solely on the grounds of such protected union activity it did not matter that they did not intend to discourage membership." 35 Unfortunately, once again the basis for the Court's holding was not made clear. The Court quoted approvingly from statements made in other contexts concerning the importance of motive. ${ }^{36}$ It avoided the reach of this language through the conclusion that in certain cases, "Both the Board and the Court have recognized that proof of certain types of discrimination satisfies the intent requirement." 37 This occurs "where employer conduct inherently encourages or discourages union membership" and "is partly an application of the common law rule that a man is held to intend the foreseeable consequences of his conduct."'38

This language was bound to lead to confusion in subsequent cases.

right is exercised for other reasons than ... intimidation and coercion." See also Associated Press v. NLRB, 301 U.S. 103, 132 (1937).

31 NLRB v. Erie Resistor Corp., 373 U.S. 221 (1963); Radio Officers' Union v. NLRB, 347 U.S. 17 (1954); Republic Aviation Corp. v. NLRB, 324 U.S. 793 (1945).

32324 U.S. 793 (1945).

33 See, e.g., NLRB v. Dalton Brick \& Tile Corp., 301 F.2d 886 (5th Cir. 1962).

34347 U.S. 17 (1954).

$35 I d$. at 46.

$36 I d$, at 43 .

37 Id. at 45 .

38 Ibid. 
The Court did not explain what it meant by conduct which "inherently encourages or discourages union membership" nor did it explain the basis for the assumption that such conduct inevitably reflects improper motive. As a result, the Radio Officers' decision has been cited both for the proposition that a finding of improper motive is necessary under section $8(a)(3)$ and for the proposition that it is not. ${ }^{39}$

A step towards clearing up the confusion was taken in $N L R B$ v. Erie Resistor Corp., ${ }^{40}$ in which the Court upheld the Board's determination that the grant of superseniority to strike replacements violated section $8(a)(3)$. The employer argued, inter alia, that as he was not motivated by a desire to discourage union membership his action was privileged. The Court rejected this argument in language which suggested that it was prepared to drop its insistence upon motive in cases involving employer response to union activity:

[A]s often happens, the employer may counter by claiming that his actions were taken in the pursuit of legitimate business ends and that his dominant purpose was not to discriminate or to invade union rights but to accomplish business objectives acceptable under the Act. ... [W] hatever the claimed overriding justification may be, [the employer's conduct] . . . carries with it unavoidable consequences which the employer not only foresaw but which he must have intended. As is not uncommon in human experience, such situations present a complex of motives and preferring one motive to another is in reality the far more delicate task, reflected in part in decisions of this Court, of weighing the interests of employees in concerted activity against the interest of the employer in operating his business in a particular manner and of balancing in the light of the Act and its policy the intended consequences upon employee rights against the business ends to be served by the employer's conduct. This essentially is the teaching of the Court's prior cases. ... . 41

Although Mr. Justice White, who wrote the opinion in Erie Resistor, emphasized balancing, he recognized that motive plays an important role in the balancing process. The basic premise of the opinion is that existence of a legitimate business purpose, though relevant, is not necessarily dispositive if achieving such purpose would require serious inter-

39 Compare Local 357, Teamsters Union v. NLRB, 365 U.S. 667 (1961), with Miranda Fuel Co., 140 N.L.R.B. 181, 186-87 (1962), enforcement denied, 326 F.2d 172 (2d Cir. 1963). See also Mountain Pacific Chapter of the Associated Gen. Contractors, Inc., 119 N.L.R.B. 883, 895 (1957); Pittsburgh-Des Moines Steel Co. v. NLRB, 284 F.2d 74 (4th Cir. 1960).

40373 U.S. 221 (1963).

41 Id. at $228-30$. 
ference with union rights. Moreover, as the opinion makes clear, if an employer is motivated by anti-union animus his action will be held to violate section $8(a)(3)$ even though it serves a valid business purpose and would otherwise have been permissible. ${ }^{42}$

Any hope that Erie Resistor would end the confusion concerning the requirement of motive ended with the Court's decision in American Ship Bld. Co. v. NLRB.43 The Board had found that the employer violated sections $8(a)(1)$ and (3) by locking out his employees in order to apply economic pressure during negotiations for a new contract, which conforms with the position it has consistently and mechanically taken that absent special circumstances a bargaining lockout improperly penalizes employees for engaging in collective bargaining. ${ }^{44}$ The Court

$42 I d$. at 227-28. Justice White suggested that when improper motive is found the need for balancing interests is over. The reason is that "such proof itself is normally sufficient to destroy the employer's claim of legitimate business purpose if one is made, and provides strong support to a finding that there is interference with union rights or that union membership will be discouraged." In the vast majority of cases this reasoning is sound. See cases cited note 14 supra. The Court has since held however thăt an employer's interest in being able to go out of business is so great that he does not violate section $8(a)(3)$ if he goes out of business completely. This is true even if he is motivated by dislike for unions and the desire to punish his employees for joining. Textile Workers v. Darlington Mfg. Co., 380 U.S. 263 (1965).

The distinction between valid business considerations and anti-union animus is not always apparent. In NLRB v. Lassing, 284 F.2d 781 (6th Cir. 1960), an employer assumed that the presence of the union would lead to increased costs. Partly on the basis of this conclusion he eliminated three jobs. The Board found a violation of section 8(a)(3). The Sixth Circuit denied enforcement on the grounds that: "The advent of the Union was a new economic factor which necessarily had to be evaluated by the respondent as a part of the overall picture pertaining to costs of operations $\therefore$. There is no evidence [of] ... anti-union background. . . The change was made because of reasonably anticipated increase costs, regardless of whether this increased cost was caused by the advent of the Union or by some other factor entering into the picture." $I d$. at 783.

The result would be unfortunate were this approach to be generally followed. Almost any conduct which penalizes employees for union membership or activity can be described in other terms. An employer who discharges employees for joining the union could claim that his actions were meant to prevent the turmoil which often occurs when some employees are union men and others are not. Typically, however, such excuses are not permitted. See cases cited in note 6 supra. In many cases, anti-union animus is based not on political convictions but on an evaluation of the effect unionization will have on profits, industrial relations, or plant conditions. Neither the Board nor the courts are equipped to separate the factors which influenced an employer in order to determine whether he was unhappy with union organization because of relevant economic considerations or because of an intent to evade the act. It seems highly unlikely that state of mind is often cast in terms of a pure and simple desire to violate the act. Nor would it be desirable to permit an employer to take into account union affiliation to the extent that a court thinks this factor reasonably related to economic reality. Such a rule would permit the economic views of individual judges to have significant impact on our labor laws.

43380 U.S. 300 (1965).

44 Morand Bros. Beverage Co., 91 N.L.R.B. 409 (1950), remanded, 190 F.2d 576 (7th 
of Appeals for the District of Columbia in a short per curiam opinion granted enforcement. ${ }^{45}$ The basis of the decision was that the function of evaluating "the conflicting legitimate interests . . the Congress committed primarily to the National Labor Relations Boad . ..." 46

The Supreme Court reversed. The majority opinion, written by Mr. Justice Stewart, heavily stressed the importance of motive to a finding of violation.

To find a violation of $\S 8(a)(3)$ then the Board must find that the employer acted for a proscribed purpose. Indeed, the Board itself has always recognized that certain "operative" or "economic" purposes would justify a lockout. But the Board has erred in ruling that only these purposes will remove a lockout from the ambit of $\$ 8(a)(3)$, for that section requires an intention to discourage union membership or otherwise discriminate against the union. There was not the slightest evidence and there was no finding that the employer was actuated by a desire to discourage membership in the union as distinguished from a desire to affect the outcome of the particular negotiations in which he was involved. ${ }^{47}$

The force of this statement was mitigated only slightly by the concession "that there are some practices which are inherently so prejudicial

Cir. 1951); Morand Bros. Beverage Co., 99 N.L.R.B. 1448 (1952), enforced, 204 F.2d 529 (7th Cir. 1953); Quaker State Oil Ref. Corp., 121 N.L.R.B. 334 (1958); American Brake Shoe Co., 116 N.L.R.B. 820 (1956), set aside, 244 F.2d 489 (7th Cir. 1957). Special circumstances justifying a lockout may be found when there is a threat of a strike likely to cause "economic losses over and beyond the ordinary loss ... attendant upon any strike." II6 N.L.R.B. at 1827, citing Betts Cadillac Oldsmobile, Inc., 96 N.L.R.B. 268 (1951). Special circumstances also exist when a union seeks to strike one member of a multi-employer bargaining unit. NLRB v. Brown, 380 US. 278 (1965); NLRB v. Local 44, Teamsters Union, 353 U.S. 87 (1957) (Buffalo Linen). The Board's conclusion in American Ship Bldg., with respect to $\$ \S 8(a)(1)$ and (3) was based partly on the theory that a lockout during negotiations penalizes employees for engaging in collective bargaining, American Brake Shoe Co., supra at 826, and partly on the theory that it constitutes unreasonable interference with the right to strike. Id. at 832. The Board apparently was of the view that the right to strike includes the right to determine the timing of the cessation of operations. See Brief for Appellee, p. 15, American Ship. Bldg. Co. v. NLRB, 380 U.S. 300 (1965). Although it did not do so for special reasons in American Ship Bldg., the Board had routinely held that a bargaining lockout violates $\S 8(\mathrm{a})(5)$ on the theory that "such conduct subjects the Union and the employees it represents to unwarranted and illegal pressure and creates an atmosphere in which the free opportunity for negotiation contemplated by section $8(a)(5)$ does not exist." Quaker State Oil Ref. Co., supra at 337.

45 Local 374, Int'l Bhd. of Boilermakers v. NLRB, 331 F.2d 839 (D.C. Cir. 1964).

46 Id. at 840 , quoting from NLRB v. Local 449 , Teamsters Union, 353 U.S. at 87,96 (1957).

47380 U.S. at 313. 
to union interests and so devoid of significant economic justification that no specific evidence of intent to discourage union membership or other antiunion animus is required." 48 As examples of such practices the Court posed situations "where many have broken a shop rule, but only union leaders have been discharged" and where "an employer permanently discharged his unionized staff and replaced them with employees known to be possessed of a violent antiunion animus." 49 The examples are misleading, because it is upon just such facts that the Board will make a finding of improper motive; it is a rare case in which the Board has more direct evidence of state of mind. A further implied concession, that a finding of improper motive is not necessary where the act complained of has "the natural tendency . . . severely to discourage union membership while serving no significant employer interests," 50 is limited by its own terms and by the Court's subsequent denial to the Board of power to balance "the competing interests of labor and management." 51

Mr. Justice White, who wrote the opinion in the Erie Resistor case, concurred specially in American Ship Bldg. on the ground that the employer had not in fact locked out.52 Had there been a lockout $\mathrm{Mr}$. Justice White would have voted to affirm on the basis of the Board's power to balance competing interests under sections 8(a)(1) and (3). He was particularly unhappy with the renewed insistence upon a finding of improper motive..$^{53}$

Whether the Court will reaffirm American Ship Bldg.'s insistence

$48 I d$. at 311 .

$49 \mathrm{Id}$. at 312 .

50 Id. at 309.

$51 \mathrm{Id}$, at 312.

52 Id. at 315.

53 "Until today the employer's true motive or sole purpose has not always been determinative of the impact on employee rights .... The balance and accomodation of 'conflicting legitimate interests' in labor relations does not admit of a simple solution and a myopic focus on the true intent or motive of the employer has not been the determinative standard of the Board or this Court. . . . The test is clearly one of choosing among several motivations or purposes and weighing the respective interests of employers and employees." Id. at 324-26. Mr. Justice Goldberg and the Chief Justice concurred on the grounds that if "this employer locked out his employees in the face of a threatened strike under circumstances where the choice of timing been left solely to the unions, the employer and his customers would have been subject to economic injury over and beyond the loss of business normally incident to a strike ...."Id. at 377. Justice Goldberg objected to the Court's emphasis on motive and to its rejection of the balancing of interests test for application of $\S 8(a)(1)$ and (3). In his view, had a proper approach based on balancing of interests been employed, the Court would not have been able to state a rule to cover all bargaining lockouts since the "types of situation in which an employer might seek to lock out his employees differ considerably one from the other." Id. at 336-37. 
upon motive is difficult to assess. Employers will undoubtedly urge its application in a variety of situations. They are most likely to contend that they may employ bargaining lockouts even before impasse is reached and also that during the course of the lockout they may hire permanent replacements. Such action might be undertaken without an "intention to discourage union membership or otherwise discriminate against the union," and even if the employer's conduct might be said to "severely discourage union membership" it could not be said to serve "no significant employer interest." According to the language of the majority opinion both factors must be present in order to "truncate ... inquiry into employer motivation." 54 Thus it is fair for Mr. Justice White to comment: "If the Court means what it says today, an employer may not only lock out after impasse consistent with $\$ \S 8(a)(1)$ and $8(a)(3)$, but replace his locked-out employees with temporary help . . . or perhaps permanent replacements, and also lock out long before an impasse is reached." 55

But there is reason to doubt that the language of American Ship Bldg. offers a safe guide to the Court's future decisions. Not only did three members of the Court specifically disassociate themselves from Mr. Justice Stewart's reasoning, but in NLRB v. Brown, ${ }^{56}$ decided the same day, the approach was markedly different. The Court there decided that an employer who legitimately locked out his employees to prevent whip-sawing by the union could hire temporary replacements in order to operate during the lockout period. The Board had held that although the lockout was privileged, the employer had violated sections $8(a)(1)$ and (3) by hiring replacements in order to stay open during the lockout. The Supreme Court reversed, but it did so only after carefully weighing the likelihood of harm to the union against the employer's interest in maintaining operations during this period. Mr. Justice Brennan, who wrote the majority opinion in $N L R B v$. Brown, recognized that a violation of section $8(a)(3)$ might be proved either by weighing these competing interests or by showing that the conduct had as its purpose the discouragement of union activity or membership. It is only

$54 I d$. at 312.

55 Id. at 324. The Court's original grant of certiorari was limited to the question "whether, under section 8(d)(4), an employer lockout is a corollary of the employees" statutory right to strike?" 379 U.S. 814 (1964). It might be argued that since this question must have been answered affirmatively, a lockout is permissible whenever a strike would be and that the employer may take whatever steps he might legitimately take during a strike. But none of the opinions refer to this limitation. The specific question for which certiorari was granted is not referred to and the final statement by the Court of its holding is quite narrow. 380 U.S. at 318. Accordingly, not too much should be made of the limitation on the grant of certiorari.

56380 U.S. 278 (1965). 
when the balancing process is resolved in the employer's favor that improper motive becomes an absolute requirement. ${ }^{57}$ This approach is consistent with the Court's prior decisions, including NLRB v. Erie Resistor Corp.,$^{58}$ where Mr. Justice White pointed out that improper motive will turn otherwise legitimate conduct into a violation of section 8 (a)(3). Thus it is very possible that in a case where the employer's conduct is more likely to be destructive of statutory rights the Court, particularly if the Board carefully weighs the competing interests, will ignore the broad language of American Ship Bldg.

There is no reason why an employer who penalizes his employees for engaging in union activity should be exonerated solely because he was not motivated by the desire to discourage union membership or activity. Where union activity provides the basis for the employer's conduct he cannot claim that his action was taken without regard to its impact on the union. ${ }^{59}$ Even if other objectives are uppermost in his mind, penalizing employees for union activity is recognized as the way to achieve these objectives. Although the employer may even regret his interference with the employee's right to engage in union activity, he has nonetheless concluded that his own interests are more important. If statutory rights are to be adequately protected this conclusion cannot be left to the discretion of the employer. The determination of whether the employer's interest is sufficient to justify the interference with employee freedom of action should be made by the Board with active supervision by the courts.

Furthermore the Board's approach to bargaining lockouts in American Ship Bldg. and other cases had not reflected the careful balancing of interests contemplated by the Erie Resistor decision; it had been doctrinaire, conceptualistic, and in need of correction by the Court. ${ }^{60}$ The Board's approach rested in part on the often stated assumption that "such conduct subjects the union and the employees they represent to unwarranted and illegal pressure and creates an atmosphere in which the free opportunity for negotiation contemplated by section 8(a)(5)

57 "When the resulting harm to employee rights is thus comparatively slight, and a substantial and legitimate business end is served, the employers' conduct is prima facie lawful. Under these circumstances the finding of an unfair labor practice under $\S 8(a)(3)$ requires a showing of improper subjective intent." Id, at 289 . Mr. Justice White dissented.

58373 U.S. 221 (1963).

59 Radio Officers” Union v. NLRB, 347 U.S. 17, 45 (1954): “[A]n employer's protestation that he did not intend to encourage or discourage must be unavailing where a natural consequence of his action was such encouragement or discouragement."

60 See Meltzer, Single Employer and Multi-Employer Lockouts Under the TaftHartley Act, 24 U. CHI. L. REv. 70 (1956). 
does not exist." ${ }^{61}$ But as courts and commentators have pointed out, ${ }^{62}$ this conclusion is directly contrary to the Supreme Court's opinion in $N L R B$ v. Insurance Agents. ${ }^{63}$ There the Court stated: "The presence of economic weapons in reserve, and their actual exercise on occasion by the parties is part and parcel of the system that the Wagner and Taft-Hartley Acts have recognized," 64 and "the use of economic pressure by the parties to a labor dispute is not a grudging exception to some policy of completely academic discussion enjoined by the Act; it is part and parcel of the process of collective bargaining." 65 The Board in balancing the competing interests of employers and unions under section $8(a)(3)$ had failed to accept the Court's conclusion that collective bargaining works best where the parties are free to use economic pressure. Considerable weight should have been given to the employer's interest in applying pressure in support of his bargaining position. The Board had failed to even consider it.

Moreover, the amount of discouragement may be small when a bargaining lockout is employed, particularly where the union and employer have had bargaining relations over a period of years. In such cases it is generally understood that the employer accepts the union and is willing to work with it. The impact, if any, of the employer's action is more likely to be on the union's bargaining position than on the allegiance of the employees to the union. Indeed, it is very possible that the reaction to a lockout will be one not of fear, but of anger, strengthening instead of loosening employee bonds with the union.

In the American Ship Bldg. Co. case the employer had a long history of engaging in collective bargaining with a group of eight unions. He had bargained in good faith with the union until an impasse was reached in the current negotiations. He was concerned about the possibility of a strike during the winter months when he "would be more vulnerable." On five preceding occasions contract negotiations were threatened by a strike. It is clear that on balance the employer's interest out-weighed the relatively slight amount of discouragement which probably resulted from his action, and that the result reached by the court was sound.

61 Quaker State Oil Ref. Co., 121 N.L.R.B. 334, 337 (1958). See also Dalton Brick \&. Tile Corp., 126 N.L.R.B. 473, 485 (1960) (and cases cited therein), enforcement denied, 301 F.2d 886 (5th Cir. 1962).

62 See, e.g., Meltzer, Lockouts Under the LMRA: New Shadows on an Old Terrain, 28 U. CHI. L. REv. 614, 619-21 (196I); NLRB v. Dalton Brick \& Tile Corp., 301 F.2d 886 (5th Cir. 1962); NLRB v. Great Falls Employers' Council, 277 F.2d 772 (9th Cir. 1960).

63361 U.S. 477 (1959).

64 Id. at 489 .

65 Id. at 495 . 
But the answer in the American Ship Bldg. case does not necessarily apply to all lockout situations. As Mr. Justice Goldberg pointed out, the balance might well be different in another case. For example, in many cases the impact of a bargaining lockout would be disastrous for the union. Where a new union is too weak to strike, an employer lockout might bankrupt the union treasury and seriously affect the allegiance of employees by demonstrating the weakness of the union. Even if done only for bargaining purposes, a lockout in such circumstances would probably carry a flavor of employer reprisal. However, there is no need for a per se approach in either case. ${ }^{60}$ Rather, the Board should be required to consider the strength of the union, the history of the bargaining relationship, the nature of the negotiation and the likelihood that the union would have struck.

\section{The Right To Go Out of Business}

Another instance in which both the Board and the courts failed to weigh competing interests carefully is Textile Workers v. Darlington $M f g$. Co. ${ }^{67}$ The case, which dealt with an employer's ability to go out of business for anti-union reasons, arose when in September, 1956, the employees of Darlington Manufacturing Company voted for union representation. In response the stockholders voted to dissolve the corporation. Darlington discontinued operations in November and sold the plant machinery at auction on December 12, 1956. The Board found that Darlington thereby violated section 8(a)(3). ${ }^{68}$ The Board's analysis proceeded solely in terms of the impact on statutory rights. No consideration was given to the importance of the employer's interest in being able to choose freely to go out of business. ${ }^{69}$

The Board ordered Darlington to refrain from such activities, to offer reinstatement to the employees if it ever resumed operations, and

66 Although a case by case appraisal would make prediction difficult, it would not be without compensations. Since the impact on employees, on the union and on industrial relations is often quite severe, it is desirable that employers be hesitant about locking out.

67380 U.S. 263 (1965).

68 Darlington Mfg. Co., 139 N.L.R.B. 241 (1962).

69 "As noted above, a partial effectuation of Darlington's threat, such as a temporary closing of the mill, or a discharge of some but not all of the employees would have violated $\S 8(a)(3)$. Yet Darlington would have this Board find that total effectuation of the threat-the permanent closing of its mill with the concomitant discharge of all its personnel-did not violate the act. In other words, under Darlington's contention an employer with a staff of 100 employees violates section 8(a)(3) if he discriminatorily fires 50 or 75 or even 99 of his 100 workers, or if he temporarily lays off all of them, but, if he retaliates against them for their union activities by permanently discharging all of them, the finality of his conduct would make it lawful. The argument is selfdefeating." Id. at 251. 
to provide "backpay until the discharged employees are able to obtain substantially equivalent employment."70 The Board also found that Darlington "occupied a single employer status with [another respondent], Deering Milliken and its affiliated corporations." 71 A separate order was directed to Deering Milliken making it liable for backpay to the same extent as Darlington and ordering it to offer the discharged employees positions at other locations to the extent they were available. The Fifth Circuit, sitting en banc, denied enforcement. ${ }^{2}$

The Supreme Court remanded. It stated that if Darlington should be regarded as a single employer it was privileged to go out of business even if "the liquidation [was] motivated by vindictiveness towards the union ...."73 On the other hand the Court held that the closing down of the Darlington Plant might constitute an unfair labor practice because of its impact on other parts of Deering Milliken's enterprise. It announced a three-step test for determining whether a plant closing violates section 8(a)(3):

If the persons exercising control over a plant that is being closed for anti-union reasons (1) have an interest in another business, whether or not affiliated with or engaged in the same line of commercial activity as the closed plant, of sufficient substantiality to give promise of their reaping a benefit from the discouragement of unionization in that business; (2) act to close their plant with the purpose of producing such a result; and (3) occupy a relationship to the other business which makes it realistically foreseeable that its employees will fear that such business will also be closed down if they persist in organizational activities, we think that an unfair labor practice has been made out. ${ }^{74}$

The case was returned to the court of appeals to consider whether Darlington was a single employer under the newly-established test.

\section{The Darlington Rule and the Rights of a Single Employer}

It is easy to understand the Court's concern in the case of a single employer. It smacks of dictatorship to force a man to stay in business against his will. As the Court stated, "A proposition that a single businessman cannot choose to go out of business if he wants to would represent . . a startling innovation."'75 It thus concluded that an

70139 N.L.R.B. at 255.

71 Ibid.

72 Darlington Mfg. Co. v. NLRB, 325 F.2d 682, 685 (5th Cir. 1963).

73380 U.S. at 274.

74 Id. at 275-76.

75 Id. at 270. 
employer has "the absolute right to terminate his entire business for any reason he pleases." 76

The word "right" is misleading when used to assert that an employer should be permitted to go out of business for anti-union reasons. It suggests not only that the act should be permitted but that no unpleasant legal consequences be attached to its exercise. Yet the conclusion that an employer should not be forced to stay in business against his will does not require the further conclusion that his conduct in closing down is outside the scope of the Act. It means only that the Board is precluded from applying certain remedies, such as an order to reopen, to correct the violation. The Board did not order Darlington to reopen, but only to compensate its employees for their losses.

Mr. Justice Harlan suggested that a complete shutdown does not contravene the policies of the act:

One of the purposes of the Labor Relations Act is to prohibit the discriminatory use of economic weapons in an effort to obtain future benefits. The discriminatory lockout designed to destroy a union, like a 'runaway shop,' is a lever which has been used to discourage collective employee activities in the future. But a complete liquidation of a business yields no such future benefit for the employer, if the termination is bona fide. It may be motivated more by spite against the union than by business reasons, but it is not the type of discrimination which is prohibited by the Act. The personal satisfaction that such an employer may derive from standing on his beliefs and the mere possibility that other employers will follow his example are surely too remote to be considered dangers at which the labor statutes were aimed. ${ }^{77}$

His reasoning is unconvincing. The impact upon other employees may be remote, but the impact upon the employees involved is direct, total, and precisely the sort of danger "at which the labor statutes were aimed." The employees of Darlington lost their jobs because they joined and voted for the union. The policy of insulating an employee's job rights from his decision whether to join a union ${ }^{78}$ is contravened whether or not the employer seeks future gain. The employer acted because he did not accept the policy of free choice expressed in the act. It is cold comfort to the employees to know that the employer was not seeking personal gain but was motivated only by spite and opposition to the exercise of statutory rights.

The Court's concern with future gain can be explained only as a

$76 \mathrm{Id}$. at 268.

77 Id. at 271-72.

78 See note 2 supra. 
way of limiting the right to shut down to those cases in which the employer acts from a deep sense of commitment and is not merely employing a labor relations tactic. When an employer operates a single business the time, energy, emotion and money which have been invested generally ensure that he will not give it up easily. Implicit in the Court's language and in the test it states is the notion that the right to go out of business exists as a safety valve for those people who feel so strongly that they are willing to substantially impair their own economic status in order to avoid dealing with a union. Paradoxically, while the Court establishes a test requiring the employer to pay a price for getting rid of a union, it does not permit the Board to add to the cost by requiring compensation for employees who are injured thereby. To require an employer to compensate his employees would reduce to a minimum the number of cases in which the safety valve is used and would afford a degree of protection to those damaged by its exercise. There is no reason why our labor policy should not be aimed at discouraging people from going out of business as a way of punishing employees for union affiliation. It may be that in some cases the Board's order would be so severe as to amount to an order to stay in business, but that danger can be met by correcting the order in the particular case. Such a possibility does not require a rule that in all cases employers may go out of business to punish his employees and may thereafter stand indifferent to the hardship caused them.

\section{The Darlington Rule and Partial Closing}

The Court's surprising failure to consider the interests of the employees directly affected colors its approach to the problem of a partial closing. The test announced apparently requires the Board to examine the employer's motives to determine whether he was acting solely out of anger towards employees who had voted for the union or whether he was motivated by a desire to chill unionism in other plants.

The clear implication of Darlington is that section $8(a)(3)$ is concerned with those who observe the employer's conduct but not with those directly affected. There is even less reason for such an approach in the case of a partial shutdown than in the case of a complete shutdown by a single employer. The element of cost to the employer who is only partially closing down is much less since he remains in business and is able to use the capital made available from closing down one part to expand the others. Whatever the employer's motive, there is likely to be some coercive effect on employees in other parts of the business. But the Court requires more than the mere likelihood of coercion: it also requires that the coercion be intended.

Moreover, the Darlington test is unrealistic. It presupposes that the 
Board is capable of sifting motives to determine whether the employer's state of mind was directed to the particular employees affected or to the employees at other plants. It is unlikely that the employer made such a distinction and even more unlikely that the Board could determine whether he did or not.

It is probable that the Court's test will be truncated where it is obvious that the shutdown plant is part of a larger enterprise. If the Board finds a coercive effect in the remaining parts of the business it is likely to assume that the effect was intended by the employer. The Court has often stated that it is proper under section $8(a)(3)$ to presume an employer intended the natural consequences of his act. ${ }^{79}$ In view of the difficulty of sorting motives in such a case, it is unlikely that the Court will demand more. Furthermore, the Board is likely to conclude that any time an employer has a publicly known interest in a plant which is shut down for anti-union reasons, it is reasonable to assume that employees in other parts of the enterprise would be put in fear that such business will also be closed down. To require more definite evidence of coercion would be to make unrealistic demands upon the Board's fact-finding processes. Thus in many situations it should be permissible for the Board to assume that employees at one plant will be coerced by an anti-union shutdown at another, and, as a result, to make the further finding that the employer so intended. If this comes about, the test stated by the Court will in fact be reduced to the question of whether it is proper for the Board to find that the shutdown plant was part of a larger enterprise.

This of course will not always be an easy question. When the issue is cloudy, the first and third tests announced by the Court offer a useful approach for resolving this question. But the language of the opinion suggests that specific findings as to "purpose and effect" are required even where it is clear that the plant closed down is part of a larger enterprise. Such a requirement is unnecessary and unrealistic.

\section{The Relation Between Section 8(a)(3) and Section 8(a)(1)}

The extent to which the Court's current concern with motive will affect the policy of protecting free employee choice will depend in part upon the extent to which the Board is able to find independent violations of section $8(a)(1)^{80}$ where it cannot find a violation of section $8(a)(3)$. Section $8(a)(1)$ is violated whenever there is "interference" with a

79 NLRB v. Brown, 380 U.S. 278, 287 (1965); Radio Officers' Union v. NLRB, 347 U.S. 17,52 (1954).

80 "Sec. 8(a). It shall be an unfair labor for an employer-(1) to interfere with, restrain, or coerce employees in the exercise of the rights guaranteed in section 7." 49 Stat. 452 (1935), as amended, 29 U.S.C. 158(a)(1) (1958). 
section 7 right. There is no need to show discrimination or encouragement, and it has long been recognized that improper state of mind is not necessary to a finding of violation. ${ }^{81}$ Section $8(a)(1)$ 's range is so great and its language so broad that a violation of any of the other subsections also violates section $8(a)(1) ; 82$ it incorporates all of the rights against employers granted by the act. Conceivably the Board could proceed under section $8(a)(1)$ in any case in which a violation of section $8(a)(3)$ is not clear.

The Board sometimes uses $8(a)(1)$ in place of $8(a)(3) .{ }^{83}$ It is likely that this approach will be continued and expanded. It was given great impetus by the recent Supreme Court decision in Burnup \& Sims, Inc. v. $N L R B .{ }^{84}$ The employer in that case discharged an employee who was soliciting for the union because the employer mistakenly thought the employee had threatened to dynamite the employer's property. The Board held the discharge a violation of sections $8(a)(1)$ and (3). ${ }^{85}$ The Court of Appeals for the Fifth Circuit denied enforcement, finding that the General Counsel had failed to show that the discrimination was "motivated by a desire to discourage protected activity." 86

The Supreme Court reversed the court of appeals and upheld the Board, but found it "unnecessary to reach the questions which were raised under section $8(a)(3)$." It concluded that the employer had "plainly violated section 8(a)(1) whatever the employer's motive." 87 The Court's reasoning was simple. Discharge of a union solicitor interferes with union organization. Section $8(\mathrm{a})(\mathrm{l})$ proscribes interference with

81 Republic Aviation Corp. v. NLRB, 324 U.S. 793 (1945).

82 See NLRB v. Express Publishing Co., 312 U.S. 426 (1941).

83 If there is no labor organization involved, $\S 8(\mathrm{a})(3)$ by its own terms is inapplicable and $\S 8(a)(1)$ must be used. NLRB v. Washington Aluminum, 370 U.S. 9 (1962); Sherry Mfg. Co., 128 N.L.R.B. 739 (1960). The Board, however, has also relied on \& 8(a)(1) in cases where a labor organization was involved. Thus in Gibbs Corp., 124 N.L.R.B. 1320 (1959), the Board held that discharge of a union steward for presenting grievances was a violation of $\S 8(a)(1)$ as interference with protected activity. The Board found it "unnecessary to decide whether the company's conduct was also violative of $\S 8(a)(3)$." 124 N.L.R.B. at 1321. The Board often employs $\S 8(a)(3)$ in such cases; see, e.g., Farmer's Union Co-op. Marketing Ass'n, 145 N.L.R.B. I (1963).

84379 U.S. 21 (1964).

85137 N.L.R.B. 766 (1962). The Board's position that a good faith belief that an employee engaged in concerted activity was guilty of misconduct was not a defense to $\S 8(a)(3)$ charge had previously been affirmed in NLRB v. Industrial Cotton Mills, 208 F.2d 87 (4th Cir. 1953), cert. denied, 347 U.S. 935, and in NLRB v. Cambria Clay Products Co., 215 F.2d 48 (6th Cir. 1954). It had been rejected in Rubin Bros. Footwear Inc. v. NLRB, 203 F.2d 486 (5th Cir. 1953).

86322 F.2d 57, 60 (1963).

87379 U.S. at 22. 
concerted activity, and its application "does not necessarily depend on the existence of anti-union bias." 88

Although the opinion by Mr. Justice Douglas purported to deal only with cases of mistaken belief by the employer the reasoning would be equally pertinent in many cases in which applicability of section $8(a)(3)$ is in doubt. Inevitably the Board will seek to take advantage of this technique and the question will be raised whether it is always appropriate to proceed independently under section 8(a)(I).

The roots of this problem go back to the original conception of the relationship between the subsections. Section $8(1)$ was thought of as the "generic" unfair labor practice and the other subsections as "species" thereof. ${ }^{89}$ This point is clearly made in the House Committee Report on the Wagner Act.

The succeeding unfair labor practices are intended to amplify and state more specifically certain types of interference and restraint that experience has proved require such amplification and specification. These specific practices, as enumerated in subsections (2), (3), (4) and (5) are not intended to limit in any way the interpretation of the general provisions of subsection (1).90

This statement contained the seeds of future confusion. To the extent that general language is given focus and specificity, its meaning is necessarily limited. It was inevitable that the language of the subsections would take on independent significance and that separate tests would be developed for section $8(a)(1)$ and the other subsections. Certain classes of cases were analysed exclusively in terms of the language of one of the other subsections, and although a violation of section $8(a)(1)$ was always found when one of the other subsections was violated such a finding was dependent upon the finding of a violation of another subsection..$^{01}$ Implicit in this development was the conclusion that in many situations section $8(a)(1)$ should not be applied without consideration of the other subsections. What constitutes "interference" with section 7 rights was to be determined by the policies and language of the other sections.

This is best illustrated by the cases dealing with the employer's bargaining obligation. Generally, it is necessary to show that an employer was improperly motivated in order to establish a refusal to bargain

88 Id. at 23.

89 Art Metals Constr. Co. v. NLRB, 110 F.2d 148, 150 (2d Gir. 1940).

90 H.R. Rep. No. 969, 74th Cong., Ist Sess. 15 (1935). See also S. ReP. No. 573, 74th Cong., lst Sess. 9 (1935).

91 See, e.g., NLRB v. Express Publishing Co., 312 U.S. 426 (1941). 
collectively under section 8(a)(5). If the improper motive is not present, there is no violation of the act and no reference is made to the language of section 8(a)(1). Thus the Supreme Court held in NLRB v. American Nat'l Ins. Co.92 that an employer willing to come to an agreement did not violate section $8(\mathrm{a})(5)$ by insisting that certain matters normally coming within the scope of the employer's bargaining obligation should be under the unilateral control of management. The Court did not attempt to determine whether the employer's conduct "interfered" with section 7 rights, despite Mr. Justice Douglas' point in Burnup \& Sims that where section $8(\mathrm{a})(\mathrm{I})$ is applied independently. "interference" may occur "despite the employer's good faith." 93 Implicit in this and other decisions construing section $8(a)(5)$ is the assumption that where in a bargaining context an employer does not violate his duty to bargain collectively under section $8(a)(5)$ he does not interfere with rights protected by section 7 .

Similarly, whether an employer gave improper assistance to a union is analysed under section $8(a)(2)$ and it is found that section $8(a)(2)$ does not apply there is no independent analysis of the applicability of section $8(a)(1) .{ }^{94}$

In the same way many of the decisions construing section $8(a)(3)$ reflect the assumption that the employer conduct involved does not violate the Act if it does not violate section $8(\mathrm{a})(3) .95$ This assumption was made explicit in the Darlington decision, in which $\mathrm{Mr}$. Justice Harlan stated that "some employer decisions . . . would never constitute violations of section $8(a)(1)$... unless they also violated section $8(a)(3)$."96 However, the Court has never really addressed itself to the distinction between conduct which may constitute an independent violation of section $8(a)(1)$ and that which should be viewed as permissible if not within the proscription of section $8(a)(3)$.

92343 U.S. 395 (1952).

93379 U.S. at 23.

94 See, e.g., Note, Section 8(a)(2): Employees' Assistance to Plant Unions and Committees, 9 STAN. L. REv. 351 (1957).

95 In Local 357, Teamsters Union v. NLRB, 365 U.S. 667 (1961), the Court rejected the Board's conclusion that employers who entered into a hiring hall arrangement with a union, absent specified safeguards, violated $\$ \S 8(a)(1)$ and $8(a)(3)$. The Court's analysis was entirely in terms of the language of $\S 8(\mathrm{a})(3)$, giving no independent attention to $\$ 8(a)(1)$. Similarly, in NLRB v. Local 449 , Teamsters Union, 353 U.S. 87 (1959), the Court affirmed the legality of a lockout to prevent whipsawing in a multi-employer situation. The Court considered $\S \S 8(a)(3)$ and $8(a)(1)$ together. In NLRB v. Dalton Brick \& Tile Corp., 301 F.2d 886 (5th Cir. 1962), the court utilized the same test previously applied for purposes of $\S 8(a)(3)$ in order to determine that the employer did not violate § 8(a)(1). Cf. NLRB v. Mriranda Fuel Co., 326 F.2d 172 (2d Cir. 1963).

96380 U.S. at 269. 
The decisions are not nearly as definite in assigning an independent role to section $8(a)(3)$ as they are with sections $8(a)(2)$ and (5). They reflect great confusion as to the relationship between sections 8(a)(1) and (3) and also as to the tests to be applied under both subsections. Many recent opinions treat them as completely independent subsections each of which might be applicable in a given case. Thus in the recent lockout decisions the Court in each case first determined that section $8(a)(1)$ was inapplicable and then proceeded to evaluate the employer's conduct under section $8(a)(3) .{ }^{97}$ There was considerable overlap in the tests employed under each subsection.

The tests traditionally applied to determine applicability of section $8(a)(\mathrm{I})$ are quite similar to those described by Mr. Justice White in Erie Resistor as determinative under section 8(a)(3). It might thus be said that the Court's present approach of independent analysis under each subsection, even if inelegant, is likely to lead to sound results. Undue insistence on motive under section $8(a)(3)$ is made harmless by independent balancing of interest under section $8(a)(1)$. The result in the Burnup \& Sims case was sound and it doesn't really matter what subsection was employed. 98

So long as the role of motive is confused under section 8(a)(3) separate analysis under section $8(a)(1)$ will have much to commend it. But this is only a stop gap solution. For one thing the court has indicated that independent analysis under section $8(a)(1)$ is not always available. And it is likely that increased use by the Board of section $8(a)(1)$ will be offset by curtailment of its independent application by the Court.

Moreover, since the Court's emphasis on motive under section 8(a)(3) reflects in part a deliberate policy decision and since section $8(a)(1)$ in particular situations tends to take on the limitations of the other subsections it is not at all unlikely that the Court will begin to require a finding of improper motive under section $8(\mathrm{a})(\mathrm{l})$. There are signs of this development in the lockout decisions. ${ }^{90}$ Such a development

97 Theoretically the determination that $\S 8(a)(1)$ was not violated included the determination that none of the other subsections of 8 (a) was violated. Cf. NLRB v. Express Publishing Co., 312 U.S. 426 (1941); Art Metals Const. Co. v. NLRB, 110 F.2d 148 (2d Cir. 1940).

98 In terms of weighing interests this was a fairly easy case. The employer interest in being able to discharge employees on the basis of a mistake in fact is not particularly strong. On the other hand, to permit such a discharge would substantially discourage employee participation in union activity because the employer must not only act properly but must appear to the employee to be doing so. That employers unhappy with union activity are prone to find misconduct where none exists is not surprising. Misconduct affords a basis for discharge and in labor relations as elsewhere "the wish is often father to the thought."

99 Thus in American Ship Bldg., the Court in its discussion of $\S 8(a)$ (1) comes close to requiring a finding of improper motive. 380 U.S. 300, 308-11 (1965). See also NLRB v. Dalton Brick \& Tile Corp., 301 F.2d 886, 898 (5th Cir. 1962). 
would be particularly unfortunate because it would add confusion to cases now properly dealt with independently under section 8(a)(1). Although the tests are similar they are not identical. Analysis under section $8(a)(3)$ is more likely to be directed to whether the employer's conduct had the effect of discouraging union membership while under section $8(a)(1)$ it is directed to whether the employer's conduct thwarted a legitimate union interest. ${ }^{100}$ Since the language of section $8(a)(1)$ is broader than that of section $8(a)(3)$ it is easier to extend it to new or borderline cases. Moreover, even if the tests were identical confusion would be bound to result from the use of different language to describe the same process under different subsections. Prospects for the orderly and coherent development of the act would be improved if rules concerning the legality of specific types of behavior were articulated within the framework of specific subsections. The cases could be most easily harmonized and future developments made more rational if the rule were adopted that employer conduct affecting a change in hire, wages or working conditions, in response to union activity, does not violate section $8(a)(1)$ if it does not violate section $8(a)(3)$ or section $8(a)(5) \cdot{ }^{101}$

\section{Employer Action Gaused by the Union}

If employees are to be free to choose whether or not to take part in union activity they must be protected against unions as well as employers. Section $8(\mathrm{~b})(2)$ of the act makes it an unfair labor practice for a union to "cause or attempt to cause an employer to discriminate against an employee in violation of subsection $8(a)(3)$..." Where a union causes an employer to take action which would violate section $8(a)(3)$ if the employer acted on his own there is no doubt that sections $8(a)(3)$ and $8(b)(2)$ are violated. The question which must be dealt with is whether the union caused conduct might be held to violate sections $8(\mathrm{~b})(2)$ and $8(a)(3)$ even where there would be no violation had the employer acted on his own.

Almost any employer action taken at the behest of a union comes within the literal definition of section $8(a)(3)$. There is discrimination because the employees are treated differently from the way they would have been treated in the absence of union activity. And such action will encourage union membership to the extent that employees learn that the union is capable of affecting the employer's conduct. The encouragement results whether or not the union is motivated by considerations of

100 See NLRB v. Brown, 380 U.S. 278 (1965).

101 Employees may engage in protected activity without a union being on the scene. If the employer retaliates against them for such activity it is hard to make out a violation of $\S 8(a)(3)$. In such cases $\S 8(a)(1)$ is employed but the tests used are the same as when $\S 8(a)(3)$ is used. NLRB v. Washington Aluminum Co., 370 U.S. 9 (1962); Sherry Mfg. Co., 128 N.L.R.B. 739 (1960). 
union membership or concerted activity. In the Radio Officers' case the Supreme Court stated "encouragement to union membership is obviously a natural and foreseeable consequence of any employer discrimination at the request of the union."102

Encouragement of this type was made the base for a finding of violation in Pacific Intermountain Express Company. ${ }^{103}$ The Board there held that a contract clause which delegated to the union control over seniority violated sections $8(b)(2)$ and $8(a)(3)$ because it was likely to encourage union membership. The Board concluded that employees would be coerced by the knowledge that the union had control over their jobs.

This decision caused much alarm among union lawyers. A union which is a bargaining representative is constantly in the position where it seeks to influence the employer's conduct. This is particularly true in processing grievances and in advancing bargaining demands. If the union is successful it will demonstrate its power over working conditions and will thereby motivate people towards membership and closer affiliation with the union leadership. Thus, many legitimate union activities could be held to violate sections $8(a)(3)$ and $8(b)(2)$ under the rationale of the Pacific Intermountain Express decision. The Board faced this probIem in the Mountain Pacific case, ${ }^{104}$ which posed the question of the legality of union operated exclusive hiring halls. Obviously if hiring is done exclusively through the union this fact will demonstrate the power of the union. On the other hand such halls serve a legitimate function and they have a long tradition. The Board recognized that "there are many literal forms of encouragement to union membership that are not prohibited," and that "a line must be drawn between lawful and unlawful encouragement."105 The Board concluded that where Congress had not specifically spelled out what constituted unlawful discouragement it was for the Board to do so. The Board did not outlaw all hiring halls. Instead it drew a line in terms of the amount of unfettered control which the union was given in the hiring hall arrangement. ${ }^{106}$

102347 U.S. 17, 52 (1954). The opinion is ambiguous with respect to its use of the term discrimination. There is language which suggests that the court viewed any differentiation between employees as discrimination. Id. at 39. And there is also language which suggests that the differentiation must be related to union activity. $I d$. at 44.

103107 N.L.R.B. 838 (1954).

104 Mountain Pacific Chapter of the Associated Gen. Contractors, Inc., 119 N.L.R.B. 883 (1957).

$105 \mathrm{Id}$. at 897-98. The Board did not deal with the meaning of discrimination.

106 In order to be lawful a hiring hall agreement had to provide: (a) that selection of applicants would be without regard to union membership; (b) that the employer had the right to reject any applicant; (c) that the parties would post the provisions of the agreement in the hiring hall and elsewhere. Id. at 897. 
The Board's Mountain Pacific doctrine was rejected by the Supreme Court in Local 357, Teamsters v. NLRB. ${ }^{107}$ In that case the hiring hall arrangement did not have the safeguards required by the Board although the contract did have a clause stating that a referral was to be "irrespective of whether the employee is or is not a member." 108 The Supreme Court refused to enforce the Board's decision on the grounds that the Board could not properly find discrimination:

But surely discrimination cannot be inferred from the face of the instrument when the instrument specifically provides that there will be no discrimination .... It may be that the very existence of the hiring hall encourages union membership. We may assume that it does. The very existence of the union has the same influence. When a union engages in collective bargaining and obtains increased wages and improved working conditions its prestige doubtless rises and one may assume more workers are drawn to it .... The truth is that the union is a service agency that probably encourages membership whenever it does a job well. But as we said, Radio Officers $v$. NLRB, the only encouragement or discouragement to the union membership banned by the act is that which is accomplished by discrimination. . . .100

The opinion is unsatisfactory. For one thing, the Court seemed unaware that the Board found discrimination of a different type than that referred to by the agreement. The opinion implies that discrimination as used in section 8 (a)(3) refers only to different treatment of union members and nonunion members. As noted above, this is inconsistent with the Court's previous decisions. The Court also seemed unaware of the Board's efforts to distinguish between unlawful encouragement and lawful encouragement.

There were real problems presented by the Mountain Pacific decision. The Board may well have exceeded its statutory authority in undertaking to distinguish between lawful and unlawful discouragements. And its conclusion that arbitrary union power of so traditional a nature constitutes unlawful encouragement is highly arguable. 110 But the decision in the Local 357 case fails to come to grips with these problems

107365 U.S. 667 (1961).

$108 I d$. at 668.

$109 \mathrm{Id}$. at $675-76$.

110 I have discussed the operation of union hiring halls with many business agents for Building Trade unions. They generally admit freely that union considerations affect their referral policies. Almost invariably they concede that such favoritism was made more difficult during the lifetime of the Mountain Pacific doctrine and surprisingly most of them think the doctrine was fair. 
and as a result it has been difficult to apply in subsequent cases.111 In Miranda Fuel Co., ${ }^{112}$ the Board was faced with interpreting its relevance in a case where a union improperly caused an employer to reduce an employee's seniority. The Board found a violation, reaffirming its conclusion that an employee is protected by section $8(a)(3)$ from union caused discipline even though the union was not motivated by considerations of union membership or concerted activity. The Board's theory in this case was similar to that announced in its Mountain Pacific decision: it did not deal with the meaning of discrimination and it found improper encouragement in the demonstration of union power. However, the Miranda decision rested on a narrower base than the conclusions in the Mountain Pacific and Pacific Intermountain Express cases that a delegation of arbitrary power to the union automatically constituted improper encouragement. In Miranda the Board further limited itself by resting on cases in which the union exercised its power in an unfair way, thereby violating its duty of fair representation under section 9(a).113

The court of appeals denied enforcement in an opinion by Judge Medina. ${ }^{114}$ The court held that to constitute "discrimination" within the meaning of section 8(a)(3) the action taken had to be based on the affected employee's union membership or activity. ${ }^{115}$ If one accepts the court's definition of discrimination it follows, as the court further concluded, that union instigated conduct does not violate the act unless based upon considerations which would be unlawful for the employer if he acted independently. ${ }^{116}$ But the court does not justify its definition and the justification is not self evident. In Allis-Chalmers Co. $v$. NLRB ${ }^{117}$ a violation was found when every member of a unit which voted union was reclassified. The employer's action was held to discriminate against the non-members who were reclassified although it was not based on their union membership or activity but on the behavior of other persons.

111 See, e.g., NLRB v. Great Falls Employers' Council, Inc., 277 F.2d 772 (9th Gir. 1960); NLRB v. Dalton Brick \& Tile Corp., 301 F.2d 886 (5th Cir. 1962).

112140 N.L.R.B. 181 (1962), enforcement denied, 326 F.2d 172 (2d Cir. 1963).

113 The Board also differentiated this case from Mountain Pacific by pointing out that the delegation of authority to the union in the Mountain Pacific case resulted in economic benefits to both the employer and the union. No such benefits were involved in Miranda. Chairman McCulloch and Board member Fanning dissented on the ground that the right to fair representation was not included in section 7 and that "the discrimination which $\S \S 8(\mathrm{~b})(2)$ and $8(\mathrm{a})(3)$ outlawed is that related to union membership, loyalty, the acknowledgment of union authority or the performance of union obligations." 140 N.L.R.B. at 197.

114 NLRB v. Miranda Fuel Co., 326 F.2d 172 (2d Cir. 1963).

$115 \mathrm{Id}$. at 179.

116 Ibid. Judge Friendly dissented. He concluded that discrimination for purposes of $\S 8(a)(3)$ meant "to differentiate without sufficient reason." $I d$. at 181.

117162 F.2d 435 (7th Cir. 1947). 
Similarly in Miranda the employer's conduct was caused by union activity although not by the union activity of the person harmed. It should be noted that it is well settled that "the Act does not require that the employee discriminated against be the one encouraged for purpose of violation of section 8(a)(3)."118

The existence of the similarity does not prove that the decision in Miranda should have followed that in Allis-Chalmers, but it does show that the problem is one of policy rather than definition. And there is no doubt that discrimination of the type involved in Miranda comes within the policy of section 8(a)(3). The purpose of isolating an employee's job from his decision as to whether or not to join a union is thwarted as much when an employee learns that his job is threatened if he angers a union official as when he learns that an employer is likely to take action against him because of concerted activity or union affiliation. It is difficult to see why employees would be more affected by the risks of concerted activity in superseniority cases than by observing that the union has power over their jobs. And there is no legitimate union interest in being able to breach its duty of fair representation. If this standard can be successfully applied under sections $8(b)(2)$ and $8(a)(3)$ the union's legitimate sphere of operation will be left untouched.

There remains, however, a risk that in policing the duty of fair representation the Board, by failing to limit itself to ensuring that the union acts in good faith, will interfere with necessary union discretion. The decision in Miranda itself is not reassuring in this regard. The Board was rather cavalier in concluding that the union breached its duty of fair representation. As the court of appeals pointed out the Board did not find that the union's contract interpretation was in bad faith. Where the union interprets a contract mistakenly but in good faith, to find a violation is contrary to the Board's often stated policy of refusing to police collective bargaining agreements. ${ }^{119}$ The same considerations which have led the Board to refuse to find an unfair labor practice where the employer misreads and misapplies the collective bargaining agreement should be applied to cases arising under sections $8(a) 3$ and $8(b) 2$. This does not mean that the courts should reject the theory adopted by the Board in Miranda. They should, however, insist that it be applied only in cases in which the union officials in selecting people for disfavorable treatment are motivated by such improper considerations as race, political affiliation, or membership in a rival union or faction..$^{120}$

118 Radio Officers' Union v. NLRB, 347 U.S. 17, 51 n.2 (1954). See discussion of Darlington Mill, text accompanying notes 69-79 supra.

119 See, e.g., In re Consolidated Aircraft Corp., 47 N.L.R.B. 694 (1943).

120 I do not think that the approach suggested by Judge Friendly is useful in this regard. Judge Friendly would limit the sweep of the doctrine by defining discrimina- 
The unmistakable tendency in the courts and Congress is towards the protection of the individual from the exercise of arbitrary power. This trend is manifested in the encouragement of arbitration and the control exercised over matters once deemed to be solely the union's internal affairs. It is misleading to equate arbitrary union action with arbitrary employer action and to say that since the act permits the one it should not be read as outlawing the other: the act itself provides a mechanism whereby collective bargaining may be required, and collective bargaining agreements almost invariably involve setting limits on management's ability to act arbitrarily. These limits are controlled in large part by the union and thus give power to union officials to punish or reward. There is no mechanism similar to collective bargaining for controlling arbitrary union action unless the duty of fair representation is given real meaning by the Board.121

\section{CONGLUSron}

The Board has been faithful to the policy which gave rise to section 8(a)(3). In applying the section it has attempted to divorce union activity from consequences on the job. Unfortunately the Board has often been single minded in its pursuit of this goal. In many cases it has failed to give adequate recognition to other important interests of employers and unions. And often it has failed to articulate the basis for its decisions. Partly as a result the courts have responded by unduly limiting application of section 8(a)(3). They have insisted upon a showing of improper motive even where the employer admittedly used union activity as the basis for his action. And the courts have not been willing to utilize section $8(a)(3)$ and $8(b)(2)$ as a way of protecting employees against arbitrary union power. The confusion which surrounds application of section $8(a)(3)$ can be resolved only if the Board shows a greater concern for and awareness of interests other than those protected by the act. Hopefully the courts would then permit its application in situations where it is now improperly denied.

tion as differentiation "without sufficient reason." Such discrimination may exist even when the union acts in good faith. Moreover, to define discrimination as differentiation without justification would be misleading and confusing as applied to situations such as superseniority or no-solicitation rules. I would therefore approach the problem not in terms of definition but of deciding which cases within the definition of $\S 8(a)(3)$ are to be viewed as a violation. In this regard the Board's solution of limiting application of the section to cases in which the duty of fair representation is breached is preferable to the approach stated by Judge Friendly.

121 The union's power in this regard has recently been strengthened by the decision in Republic Steel Corp. v. Maddox, 379 U.S. 650 (1964), which held that an employee could not handle a grievance by himself but had to "afford the union an opportunity to act on his behalf." 